\title{
ポリ(ジーnーヘキシルシリレン) 配向薄膜の構造と光物性
}

\author{
谷垣 宣孝*1 ·吉田 郵司*1 ·京谷 裕子*2 \\ 海藤 彰 ${ }^{* 3} \cdot$ 八瀬 清志 ${ }^{* 1}$
}

（受付 2002 年 6 月 3 日・審査終了 2002 年 7 月 24 日）

\begin{abstract}
要 旨 ポリ(ジーnーヘキシルシリレン)（PDHS）の配向薄膜を摩擦転写法によって作製した。この薄 膜の作製温度条件を検討し, 高配向薄膜について配向構造を分光法, および全反射 $\mathrm{X}$ 線回折法によって 評価した．その結果，PDHS 分子鎖は摩擦方向に平行に配向しており，さらに基板に対しても特定の配向 をしていることがわかった．また，摩擦転写膜の相転移前後における配向を評価した結果，配向をほほ保 つたまま相転移すること，高温相から低温相に再結晶化するときに配向が若千乱れることが観測された。 さらに配向薄膜の偏光蛍光スペクトルを測定し, エネルギー移動を観察した。
\end{abstract}

\section{1 緒言}

主鎖がすべてケイ素からなる高分子，ポリシランはそ の特徵的な電子物性から光電子材料として興味をもたれ てきた。 その電子物性はケイ素ーケイ素結合を介して広 がる $\sigma$ 電子に由来している。この現象は $\sigma$ 共役と呼ば れる. $\sigma$ 共役は $\pi$ 共役と同様に，高分子に半導体性を もたらす．電子がケイ素一ケイ素単結合に沿って非局在 化しているため, ポリシランの $\sigma$ 共役性はこの結合の コンホメーションに大きく依存する，例えば，本報で述 ベるポリ(ジーnーヘキシルシリレン) (PDHS), [Si $\left(\mathrm{C}_{6}\right.$ $\left.\left.\mathrm{H}_{13}\right)_{2}\right]_{\mathrm{n}}$, は熱によって構造相転移を起こし, コンホメー ションを変える．このとき光吸収が大きく変わるサーモ クロミズムを示す1),2). 比較的リジットな結合をもつ $\pi$ 共役系高分子と異なり，ポリシランでは構造と電子物性 とが密接に関係していることから構造の観点から多くの 研究がなされている．また，この非局在化電子は主鎖に 沿って広がっているため分子鎖の配列を制御することに よって電子機能を向上させたり, 機能に異方性を付与し たりすることが可能になる。

筆者らは摩擦転写法をポリシランに適用し, いくつか のポリシランの配向薄膜を作製し, その構造と物性を研 究してきた3) ${ }^{29}$. 摩擦転写法は高分子の固体と基板とを こすり合わせることで高分子の薄い膜を基板表面に形成

*1 産業技術総合研究所光技術研究部門（③05-8565つくば市 東 1-1-1)

*2 元 物質工学工業技術研究所 (®305-8565つくば市東 1-1-1)

*3 産業技術総合研究所高分子基盤技術研究七ンター (『305-8565つくば市東 1-1-1)

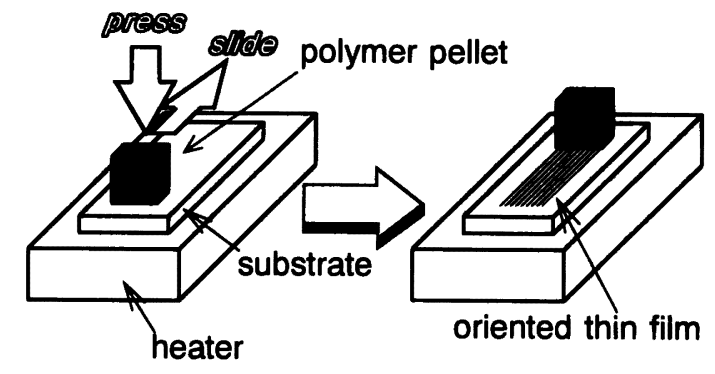

Fig. 1. Schematic drawing of friction transfer method.

する技術であり，摩擦転写したポリ (四フッ化エチレン) （PTFE）がさまざまな分子を配向させることから注目を 浴びた(0). 摩擦転写では固体から直接薄膜を作製するこ とができるので，一部の不溶性の高分子にも適用でき， ポリジメチルシリレン（PDMS）などの不溶性ポリシラ ンの超高配向薄膜を作製することができた3),4),9). 摩擦転 写法の概念図を Fig. 1 に示す.

本報では可溶性ポリシラン PDHS の摩擦転写薄膜に ついて報告する. PDHS はもっともよく研究されている ポリシランといってよい. PDHS はケイ素主鎖骨格とす ベてのケイ素原子に結合したアルキル側鎖である二つの $n$ ーヘキシル基とからなる. PDHS が注目される一つの理 由は溶液中および固体でサーモクロミズムを示すことに ある.前述したように,これは主鎖骨格のコンホメーシ ヨンの変化を伴う. 固体の場合, 低温相では全トランス コンホメーションをとり, 高温相では乱れた分子構造に なると考えられている. 結晶格子も斜方晶から六方晶に 転移する. 低温相の結晶構造はX 線回折による研究が 
なされている(1),12). 実際は高温相，低温相だけではなく 非常に複雑な固相転移が報告されているが，本報では単 純化し, 低温相と高温相に代表させる.PDHS の配向薄 膜については延伸法 ${ }^{(3), 14) ， ラ ヒ ゙ ン ク ゙(5) な と ゙ ， さ ま さ ゙ ま な ~}$ 方法で作製されている，摩擦転写 PTFE 膜上にキャスト することで配向させた薄膜についても報告がある ${ }^{16)}$. 応 用面では, 非線形光学 ${ }^{17)}$, 電界発光 ${ }^{18)}$ などが検討されて いるが, 特に非線形光学特性は分子の配向が重要な因子 となっている. 本報では摩擦転写膜の詳細な構造, そし て相転移が配向構造に与える影響について述べる。ポリ シランの相転移と配向の関連についてはほとんど研究例 がない. また, 配向薄膜の蛍光スペクトルについても述 べる.

\section{2 実験}

\section{1 試料}

2.1.1 PDHS の合成 PDHS はジー $n$ ーヘキシルジクロ ロシランをナトリウムによって Wultzカップリング法で 重合した。PDHS は再沈法により高分子量成分のみを分 離して使用した。重量平均分子量はポリスチレン換算で $M_{\mathrm{w}}=4.5 \times 10^{5}$ であった。

2.1.2 摩擦転写法 PDHS 配向膜は摩擦転写法によっ て以下のように作製した. PDHS はペレット状に加圧成 型し, さらに切り出し平滑面を作った。ペレットの平滑 面を温度を制御した基板に押しつけ，一方向に掃引し， 基板表面へ高分子薄膜を形成した，基板には用途に応じ て, ガラス基板, 石英基板, 臭化カリウム（KBr）単結 晶基板を用いた。

\section{2 測定}

2.2.1 分光測定 紫外一可視吸収 (UV) スペクトルは (株)島津製作所製の MPS 2000 を用いて測定した.また， 蛍光スペクトルは日本分光(株)製の FP-777 を使用して 測定したＵVスペクトル，蛍光スペクトルにおける偏 光測定は Glan-Thompson 偏光プリズムを用いて行った. UVスペクトルの温度変化測定はヒーターを仕込んだ真 ちゅうブロックからの熱伝導式セルを用いて行った. 赤 外吸収（IR）スペクトルは Bio-Rad Laboratries, Inc. 製の FTS-60 A/896 FT-IR 用いて測定した. IRスペクトル の偏光測定にはワイヤーグリッド偏光子を用いた。

2.2.2 形態観察 形態観察 (膜厚測定) は偏光顕微鏡, 表面粗さ計（TENCOR Instruments 製 Alpha-Step 300 プ ロファイラー), 透過電子顕微鏡によって行った. 透過 型電子顕微鏡（TEM）観察は Carl-Zeiss Co. Ltd. 製 CEM 902 を使用して行った. $\mathrm{KBr}$ 基板上に作製した薄膜を非 晶質カーボンで補強し，水面上で基板からはく離し，銅 メッシュ上にすくい取り, 試料とした.

2.2.3 全反射 $X$ 線回折法 全反射 $X$ 線回折 (TRXD) 法は試料表面に対して非常に小さい角度で X 線を入射
し, 試料と基板との界面で $\mathrm{X}$ 線を全反射させることに よって, 基板からの散乱をおさえ, 薄膜試料のみからの 良好な回折デー夕を得るという方法である ${ }^{19), 20)}$.この方 法のもう一つの特徵は通常の X 線回折法における薄膜 の厚み方向の繰返し周期に対応した回折に加え, 薄膜の 面内の繰返し周期に対応する回折を得ることができると いう点である，さらに，薄膜面に対して任意の角度をな す回折面をもつ反射を測定することができる（全方位測 定）ため，薄膜内の分子配列に関する情報を詳細に調べ ることが可能である。詳細は既報に述べた ${ }^{21)}$.

本研究に用いた装置の特徵はエネルギー分散型の測定 のため, 回折をエネルギースペクトルとして得ることに ある. Bragg の式から hkl 反射格子間隔 $d_{h k l}$ と回折 $\mathrm{X}$ 線 のエネルギー $E_{h k l}$ との関係は次のように表される.

$$
E_{h k l}=h c n / 2 d_{h k l} \sin \theta
$$

ここで $h$ はPlanck 定数, $c$ は光速, $n$ は反射の次数, $\theta$ はBragg 角（固定）を表す．通常の回折角を変化させて 測定する角度分散型と比較し, 光学系が単純で, かつ光 学系を固定して測定できるため, 薄膜内の分子配向を迅 速簡便に評価することができる. また, エネルギー分散 型を用いることにより全反射条件を崩すことなく全方位 測定が可能になる.

測定には理学電機 (株) 製の試料水平ゴニオメーターを もとに作製したものを用い, モリブデン管球からの白色 $\mathrm{X}$ 線を光源とし, 回折プロファイルは純ゲルマニウム半 導体検出器によってエネルギースペクトルとして測定し た. 試料の温度は水平試料台に仕込んだヒーターによっ て制御した。

\section{3 結果と考察}

\section{1 配向膜の作製}

摩擦転写法によって PDHS 高配向膜を得ることがで きることはすでに簡単に報告した ${ }^{5), 81,221 . こ こ て ゙ は P D H S ~}$ 摩擦転写膜の作製条件について詳細に述べる。すでにい くつかのポリシランにおいて摩擦転写膜の性質は作製時 の基板温度に大きく依存することは報告したが3),5),8), PDHS においても作製時の基板温度は重要であった. Fig. 2 に三つの代表的な基板温度域で作製したPDHS 薄膜の 偏光 UV スペクトルを示す (測定は室温で行った). PDHS は $42^{\circ} \mathrm{C}$ で低温相（全トランス骨格をもつ）から乱れた 高温相（メゾフェーズ）に転移する. 全トランス構造に 由来する吸収は $370 \mathrm{~nm}$ 付近に, 乱れた構造に由来する 吸収が $310 \mathrm{~nm}$ にあり, サーモクロミックな相転移を起 こすことが知られている．図からわかるように室温では 摩擦転写薄膜に両方の相が共存している。これは溶液か らのキャスト膜と同様である.いずれの試料においても， 全トランス構造の部分の方が乱れた部分よりも高配向で 

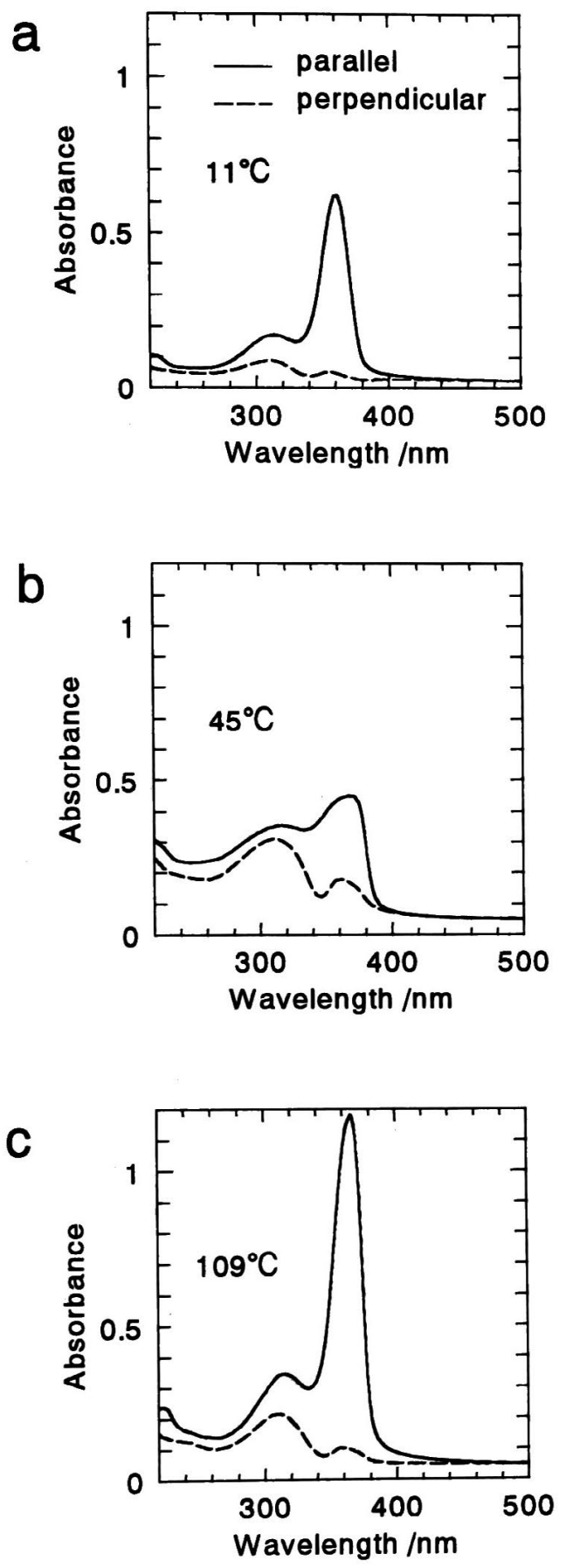

Fig. 2. Polarized UV spectra of friction-transferred PDHS film prepared at $11^{\circ} \mathrm{C}$ (a), $45^{\circ} \mathrm{C}$ (b), and $109^{\circ} \mathrm{C}$ (c).

あることがわかる，転移温度より低温で作製した膜は低 温相成分を多く含み, 配向度も高い (Fig. 2 a). 転移点 付近 $\left(35 \sim 45^{\circ} \mathrm{C}\right)$ で作製した膜は配向度が低く，全トラ ンス成分も少ない (Fig. 2 b). 転移点付近では分子が構 造を変化させているため配向しにくいためであろうと考 えられる。 さらに高温で転写することによって高配向の ものが得られた (Fig. $2 \mathrm{c})$. 高温で作製した薄膜では低

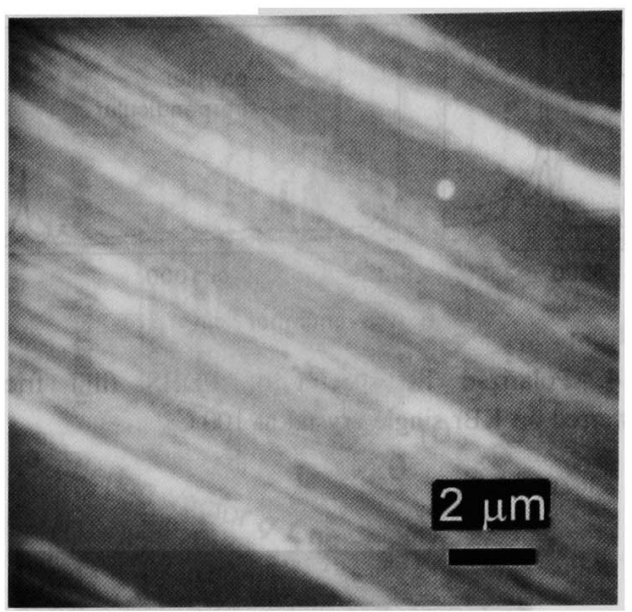

Fig. 3. A transmission electron micrograph of PDHS film friction-transferred at $109^{\circ} \mathrm{C}$.

温相の割合も比較的多くなっている，本報のこの節以降 では低温相を多く含む薄膜を使用した。

Fig. 3 に透過電子顕微鏡写真を示す. 偏光顕微鏡観察 から膜全体が一方向に配向していることがわかった．高 配向膜が得られたが, どの温度域でも PDMS などの不 溶性高分子と比べ均一な薄膜は得られなかった，薄膜の 厚さは粗さ計の測定で $10 \sim 200 \mathrm{~nm}$ と幅広く分布してお り, TEM 像から連続膜ではなくひも状のものから形成 されていることがわかる.この構造は PDMS 摩擦転写 膜のものよりかなり大きい4.

\section{2 配向膜の構造}

Fig. 2 の偏光 UV スペクトルを見ると摩擦方向に平行 な成分がより強く吸収されていることがわかる，ポリシ ランの主鎖電子の遷移に由来する吸収の遷移ベクトルの 方向は主鎖方向に一致することが知られており ${ }^{231}$, 偏光 UV から PDHS の主鎖は摩擦方向に平行であることがわ かる.

Fig. 4 に PDHS 配向膜の偏光 IR スペクトルを示す. この偏光スペクトルは以前報告された高配向 PTFE 膜上 にキャストすることで配向したPDHSのものと類似し ている(6). $600 \mathrm{~cm}^{-1}$ より高波数の IR バンドはすべてア ルキル側鎖に由来するものであると考えられる。これが 顕著な二色性を示していることから PDHS 摩擦転写膜 では主鎖のみならず，側鎖も高度に配向していることを 示している.これは側鎖の結晶化に起因していると考え られる. スペクトルの平行成分には $2920 \mathrm{~cm}^{-1}, 660 \mathrm{~cm}^{-1}$ の二つの非常に強い平行バンドが観測されている. 2920 $\mathrm{cm}^{-1}$ のバンドは側鎖の $\mathrm{CH}_{2}$ 非対称伸縮振動に帰属でき る.このバンドはアルキル側鎖をトランスジグザグ構造 で近似した場合そのジグザグ面に対して垂直方向の二色 性をもつ.このバンドが平行成分として現れていること はアルキル側鎖のジグザグ面が主鎖方向に垂直であるこ 


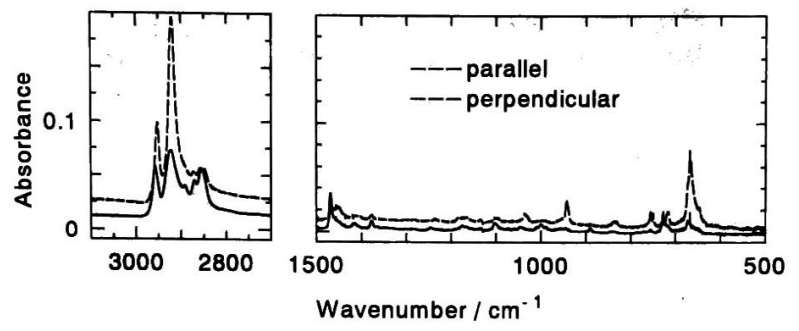

Fig. 4. Polarized IR spectra of PDHS film frictiontransferred on $\mathrm{KBr}$ single crystal at $100^{\circ} \mathrm{C}$.

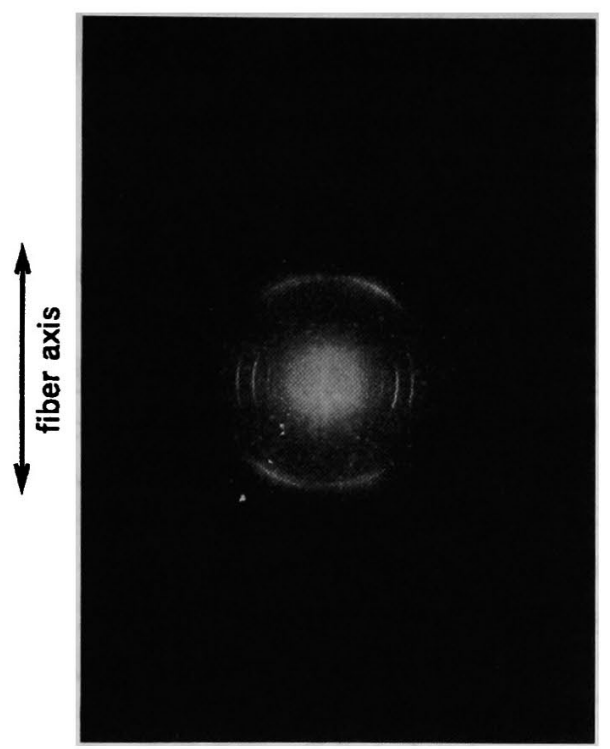

Fig. 5. Electron diffraction of PDHS film prepared at $100^{\circ} \mathrm{C}$.

とを示している。これは古川らのX線回折によって導 き出されたPDHS 低温相の結晶構造モデルとよく一致 する(2) (Patnaik と Farmerのモデル'11 とは一致しない). 一方 $660 \mathrm{~cm}^{-1}$ のバンドは, 以前の報告では $\mathrm{Si}-\mathrm{C}$ 伸縮振 動に帰属されていたが(6),24), Si-C 伸縮振動は平行バンド にはなりえず，今回の実験結果と矛盾する．筆者らはこ のバンドを $\mathrm{Si}-\mathrm{C}$ 伸縮振動ではなく，(Si-) $\mathrm{CH}_{2}$ 横ゆれ振 動に帰属した，Si-C 伸縮振動は今回観測できなかった より低波数域にあると考えられる.

Fig. 5 は PDHS 配向膜の電子線回折写真である.鋭い 回折が見られ，高結晶性を示している。 また回折パター ンは基本的に既に報告されたバルク試料のものと類似し ており, 薄膜特有の特殊な結晶構造をとっていないこと を示している，反射は弧状になっており，ある程度配向 が乱れていることを示している，しかし，電子線回折測 定では基板からはく離して測定するため，そのときに配 向が乱れた可能性がある。

全反射 $\mathrm{X}$ 線回折法では試料を基板からはがすことな

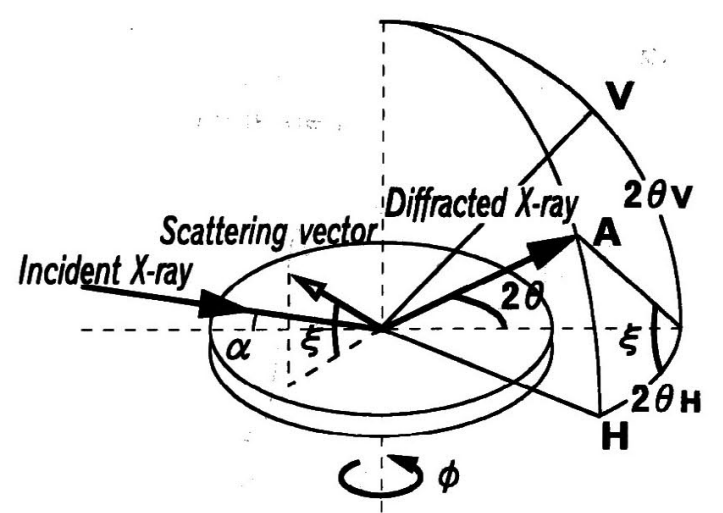

Fig. 6. Schematic drawing of TRXD geometry.

く測定することができるので薄膜の本来の配向構造を知 ることができる．摩擦転写膜では分子鎖方向が 1 軸配向 しているだけではなく高分子微結晶が 3 次元的に配向し ており，分子鎖軸以外の軸が基板面に対して，特定の配 向をしていることをいくつかの試料で確認した211,25),26). 本研究ではPDHSのもっとも強く観測される低温相の 110 反射に注目し, 摩擦転写配向薄膜中の結晶の配置 (分 子の配向)を調べた. PDHS の低温相では 020 反射と 110 反射とは面間隔がほほ同じ $\left(q=5.24 \mathrm{~nm}^{-1}\right)$ で $\mathrm{X}$ 線回折 では区別することができない．以下 110 反射で 110,020 反射を代表させる．まず，110 面が基板面に对してどの ように配置しているかを調べた．Fig. 6 に TRXD 測定の 光学系を示す. $c$ 軸（繊維軸，分子鎖軸に一致）が基本 的に摩擦方向に平行であることを利用し試料面の回転角

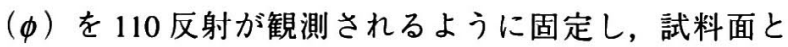
散乱べクトルとのなす角 $(\boldsymbol{\xi})$ を変えて 110 反射を測定 した. Fig. 7 にを変えて測定した全反射 $\mathbf{X}$ 線回折プ ロファイル，および 110 反射の強度分布を示す. $\boldsymbol{\xi}$ が $30^{\circ}$ および $90^{\circ}$ のときに 110 反射が強く観測されることがわ かる. Fig. 8 のような結晶配置のモデルを考えることに より Fig. 7 の観察結果が説明できた. Fig. 8 の左側の二 つのモデルはいずれも今回の結果を説明することがで き，両者は今回の実験結果では区別できない。この配向 構造は京谷らが報告しているキャスト膜の自発的面配向 と同様のものであり ${ }^{27)}$, 摩擦転写薄膜中では PDHS 分子 鎖は基板面に対して安定な配向をとっていると考えられ る.

次に，傾き角 $\xi$ を固定し，試料面 $\phi$ を回転し，110 反射を測定することで面内の $c$ 軸の配向分布を評価し た. Fig. 9 は $\phi$ を変化させて測定した全反射 X 線回折 プロファイル，および 110 反射の強度分布を示す. 110 および 020 反射は分子鎖軸に垂直な方向の反射であり， この反射の分布を示す Fig. $9 \mathrm{~b}$ は主鎖方向の配向分布を 示しているといえる.この分布はガウス分布で近似でき， 
a

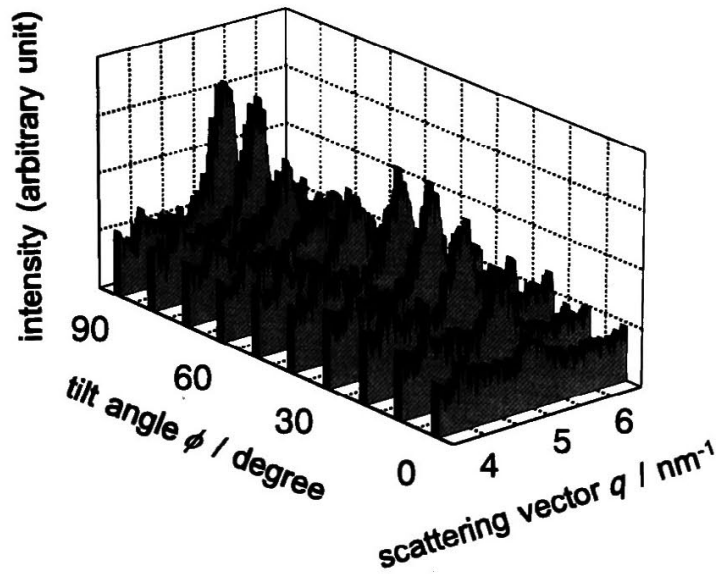

b

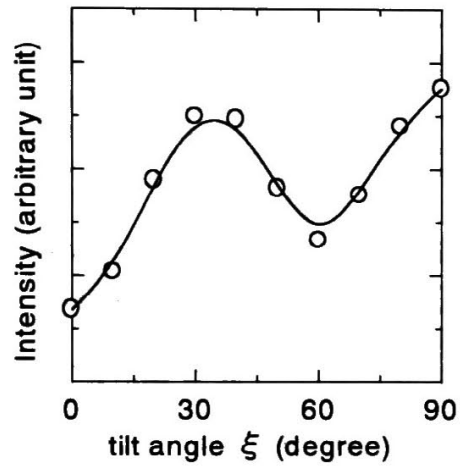

Fig. 7. (a) Series of $\mathrm{X}$-ray diffraction profiles taken with various $\xi$ angles between the diffraction plane and the substrate plane. The diffraction angle $2 \theta$ was fixed at $4.5^{\circ}$. (b) The changes in the relative intensity of PDHS $110+020$ reflection depend on the $\xi$ angles. The PDHS film was friction-transferred at $100^{\circ} \mathrm{C}$.

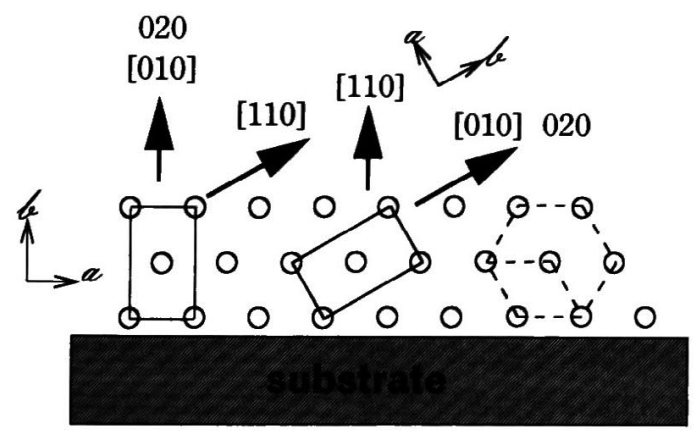

Fig. 8. Model for the arrangement of PDHS crystallites. The $c$ axis is normal to this paper plane. Two crystal unit cells at the left side present the lower temperature phase and a unit cell at right side shows the higher temperature phase.

その半値幅は $24^{\circ}$ であった. TRXD 法で求めた摩擦転写 PTFEの配向分布より広いが21, 比較的高配向であるこ とを示している. a

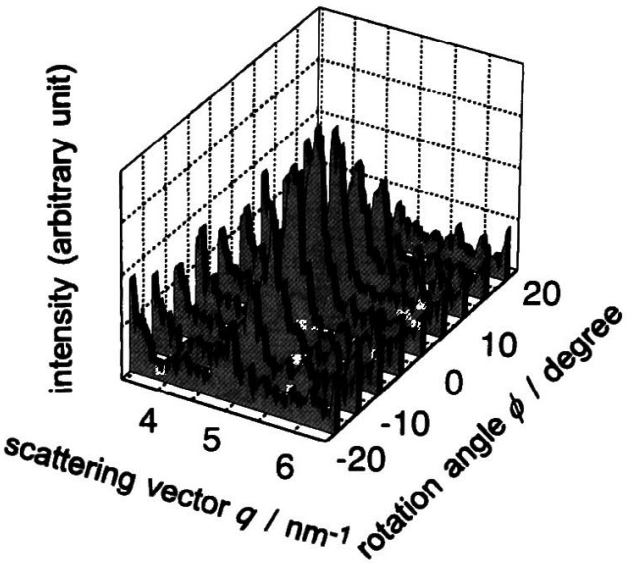

b

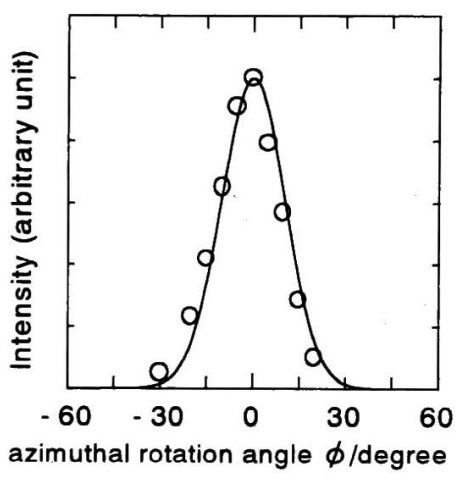

Fig. 9. (a) Series of $\mathrm{X}$-ray diffraction profiles taken with various azimuthal rotation angles $\phi\left(2 \theta=4.5^{\circ}, \xi=30^{\circ}\right)$. (b) Azimuthal-angle-dependent changes of the relative intensity of the PTFE $110+020$ reflection. The PDHS film was friction-transferred at $100^{\circ} \mathrm{C}$.

\section{3 相転移と配向構造の関係}

摩擦転写膜はバルク試料同様, サーモクロミック転移

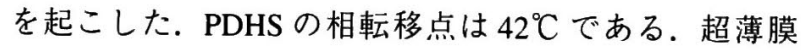
$(10 \mathrm{~nm}$ 以下 $)$ では相転移点の低温シフトが観測されて いるが28,29, 摩擦転写薄膜においてはバルク試料と比べ 大きな転移点の変化がなかった. 本研究の摩擦転写膜が 比較的厚い（100 nmオーダー）からであろう. Fig. 10 は偏光 UVスペクトルの温度变化を示す，高温相におい ても二色性を失わなかった。また，ふたたび低温相に戻 しても配向は大きく変化しなかった。再度室温に戻した 場合, 熱処理効果により加熱前より全トランス成分が増 加していた，相転移前後において大きな配向度の低下は なく, 分子構造が変化する相転移を経ても分子鎖の配向 が大きく変化しないことがわかる．しかし，ふたたび室 温に戻したとき若干配向度が低下しているように見え る.しかし, 偏光 UV スペクトルから求めた配向度では 配向変化の詳細を検討するのは困難である.

PDHS 配向膜の TRXD 温度変化を測定した. 室温にお いて 110 反射がもっとも強く観測できる光学系の配置に 
a

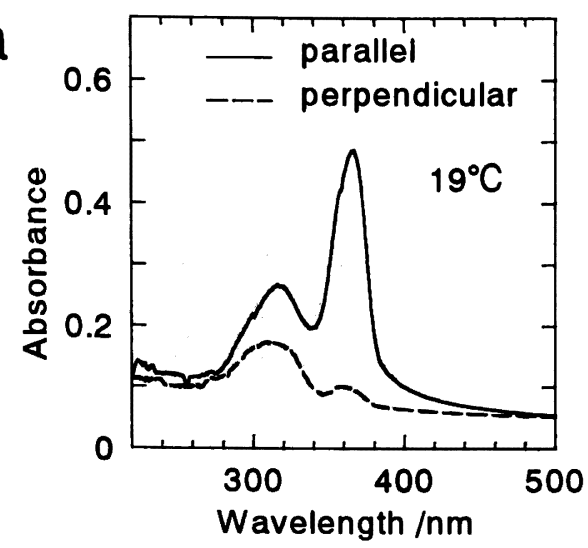

b

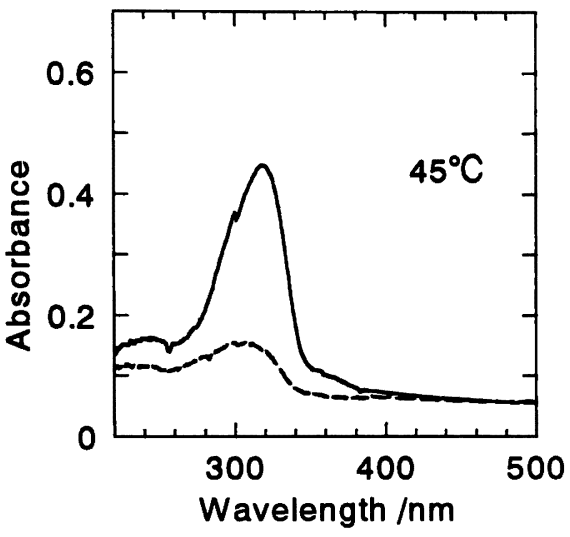

C

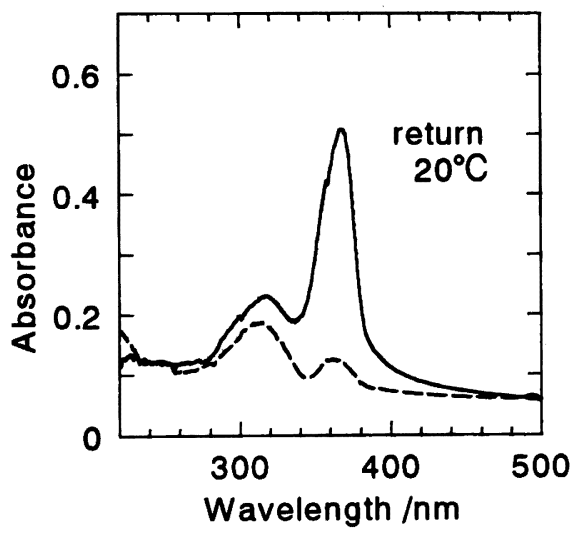

Fig. 10. Temperature dependent polarized UV spectra of PDHS friction-transferred at $19^{\circ} \mathrm{C}$; measured at $19^{\circ} \mathrm{C}$ (a), $45^{\circ} \mathrm{C}$ (b), and $20^{\circ} \mathrm{C}$ (c). The PDHS film was frictiontransferred at $100^{\circ} \mathrm{C}$.

おいて温度変化を行った．そのときのプロファイルの変 化を Fig. 11 に示す. $40^{\circ} \mathrm{C}$ を超えると 110 反射が消失し， 新たに散乱べクトル $q$ が小さい回折 $\left(q=4.7 \mathrm{~nm}^{-1}\right)$ が 出現した。これは高温相 100 反射で，高温相への転移を 示している．右側の降温過程においても転移点は低温側 にずれるものの，相転移を観測できた． a

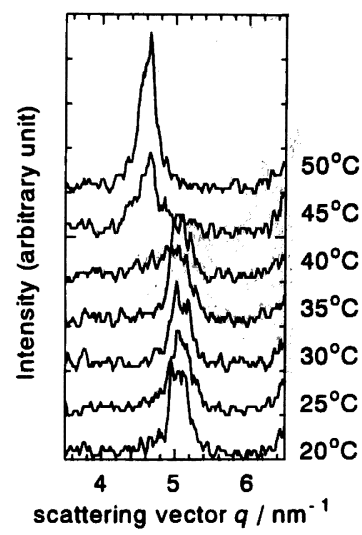

b

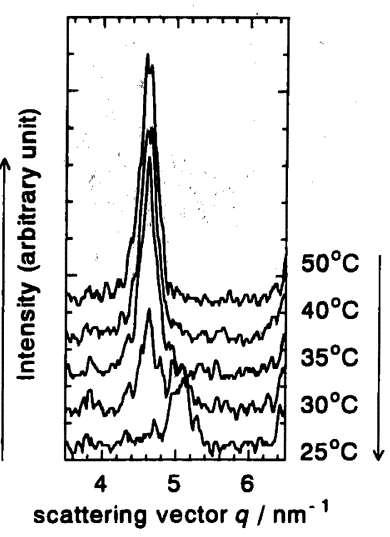

Fig. 11. The temperature-dependent changes of the diffraction profile of PDHS film in the heating process (a) and the cooling process (b). The PDHS film was friction-transferred at $100^{\circ} \mathrm{C}$.

高温相における配向分布，および室温に戻したあとの 配向分布を測定した（Fig. 12）. Fig. 12a は傾き角 $\xi を$ 変化させたときの回折強度の変化を示し, 基板面に対す る結晶面の配置を表している. 高温相においても低温相 同様, 傾き角 $\xi=30^{\circ}, 90^{\circ}$ において回折強度はピークを もつ. 高温相は六方晶系であるので, 分子鎖は基板面に 対して最密充てん配置をしていると考えられる. Fig. 8 右の配置である。 また, 室温に戻した場合の低温相の結 晶配置は転移前のものと基本的に同じである（格子サイ ズは変化する)，相転移前後の結晶配置の関係を考察す る. 低温相である斜方晶格子の分子の配置と高温相の六 方晶の分子配置は基本的に同じである. 六方晶では分子 は回転対称的であるが斜方晶では主鎖全トランス分子面 が決まった配置となる．このときの分子面の向きの違い で 110 面配向, 020 面配向の 2 種が存在することになる と考えることができる．この現象を考えると，製膜時に も同様のことが起こっている可能性があると思われる。 すなわち, 摩擦転写の際, 基板界面で PDHS の一部が 滑りやすい高温相に転移し，基板に移り，基板上で再結 晶し配向膜になるという製膜メカニズムが考えられる.

Fig. $12 \mathrm{~b}$ は試料面 $\phi$ を変化させたときの回折強度の 変化を示している. 低温相から分子構造が乱れた高温相 に変化しても主鎖方向の配向分布はほとんど変化がな い.これに対して高温相から低温相に再結晶する際に分 子配向が乱れたことが見てとれる.配向分布の半值幅は $45^{\circ}$ に広がる.これは偏光 UV スペクトルの温度変化に おいても観測されている (Fig. 10). PTFE 摩擦転写膜に おいては相転移前後で主鎖の配向分布がほとんど変化し ない211.これは基板からの拘束力が強いからであると考 えられるが, PDHS では膜が厚いため基板界面からの拘 
a

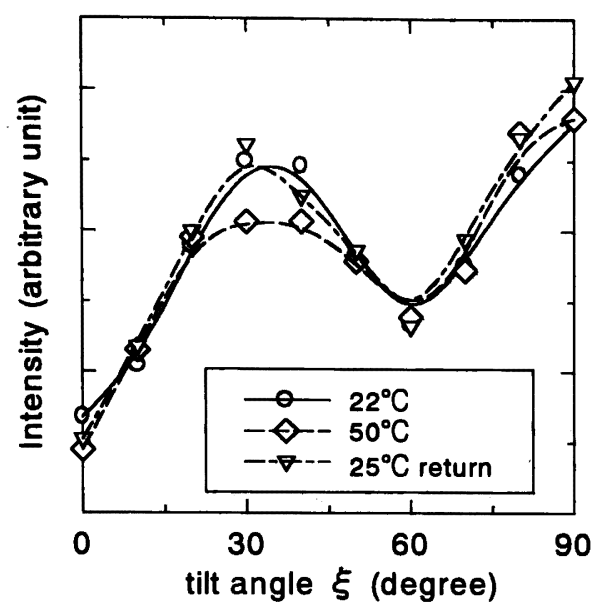

b

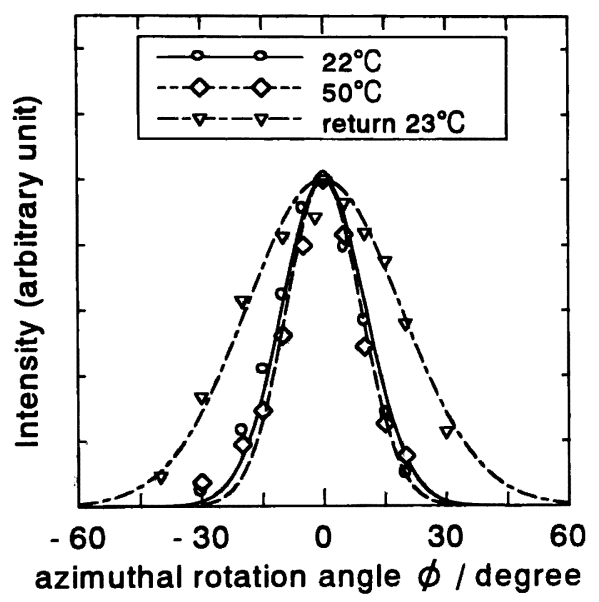

Fig. 12. Temperature-dependent changes of the relative intensity distribution of $110+020$ reflection. (a) $\xi$ dependence and (b) $\phi$ dependence. The PDHS film was frictiontransferred at $100^{\circ} \mathrm{C}$.

\section{束を受けにくいためであろうと考えられる。}

\section{4 配向膜の蛍光}

摩擦転写法によって作製したPDHS 配向薄膜の偏光 蛍光スペクトルを測定した. 蛍光の検出側だけではなく， 励起光側にも偏光子を使用し 4 成分を測定した. $z$ 軸を 摩擦方向の主軸としそれに垂直な方向を $x$ 軸にとった。 励起光の偏光子が $i$ 方向で, 蛍光側の偏光子が $j$ 方向の 場合の蛍光強度を $I_{i j}$ と表す $(i, j=x, z)$. Fig. 13 a は 350 $\mathrm{nm}$ の光で励起したとき, Fig. $13 \mathrm{~b}$ は $310 \mathrm{~nm}$ の光で励起 したときの偏光蛍光スペクトルをそれぞれ示している. $350 \mathrm{~nm}$ 励起の場合, $I_{::}$成分, すなわち摩擦方向に平行 な光で励起したときの摩擦方向の偏光が飛び抜けて強 い. 一方, $310 \mathrm{~nm}$ 励起の場合, $I_{z z}$ 成分はもっとも強い ものの, 前者の場合と比べ, $I_{x:}$ が比較的強く観測され た. 蛍光はいずれの場合も $380 \mathrm{~nm}$ 付近にピークをもち, 全トランス鎖(低温相)から発光していると考えられる. a

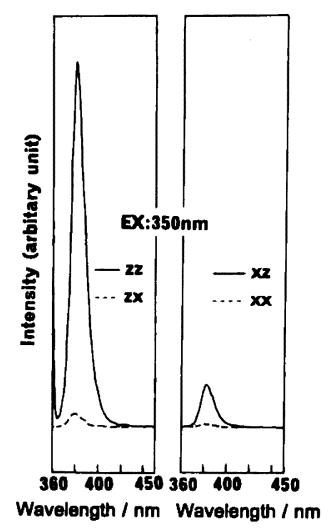

b

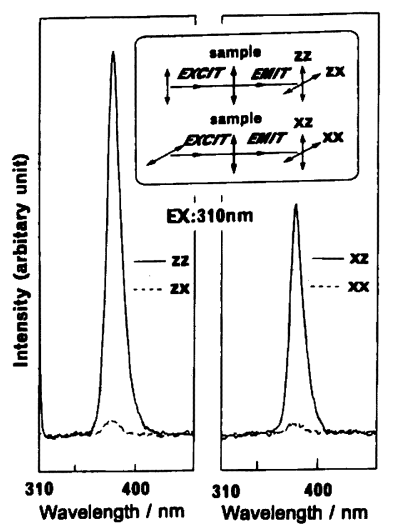

Fig. 13. Polarized fluorescence spectra of PDHS excited at $350 \mathrm{~nm}$ (a), and $310 \mathrm{~nm}$ (b) and the schematical drawing of the optical system of the polarized fluorescence measurements. The PDHS film was friction-transferred at $109^{\circ} \mathrm{C}$.

Table 1. The degrees of orientation of the PDHS frictiontransferred film

\begin{tabular}{ccccc}
\hline \hline $\begin{array}{c}\text { prep. tempera- } \\
\text { ture }\left({ }^{\circ} \mathrm{C}\right)\end{array}$ & $\begin{array}{c}f_{\text {ex }} \\
(350 \mathrm{~nm})\end{array}$ & $\begin{array}{c}f_{\text {em }} \\
(350 \mathrm{~nm})\end{array}$ & $\begin{array}{c}f_{\text {ex }} \\
(310 \mathrm{~nm})\end{array}$ & $\begin{array}{c}f_{\text {em }} \\
(310 \mathrm{~nm})\end{array}$ \\
\hline 11 & 0.751 & 0.800 & 0.529 & 0.700 \\
19 & 0.679 & 0.717 & 0.501 & 0.631 \\
24 & 0.762 & 0.796 & 0.540 & 0.681 \\
31.5 & 0.584 & 0.656 & 0.386 & 0.559 \\
40 & 0.492 & 0.587 & 0.355 & 0.516 \\
45 & 0.486 & 0.592 & 0.374 & 0.543 \\
92.5 & 0.641 & 0.691 & 0.509 & 0.618 \\
109 & 0.773 & 0.842 & 0.440 & 0.682 \\
\hline
\end{tabular}

$350 \mathrm{~nm}$ 励起の場合，全トランスセグメントが励起され， 全トランスセグメントが発光している。一方 $310 \mathrm{~nm}$ 励 起の場合は乱れたセグメント（高温相）を励起し, 全卜 ランスセグメントが発光するという，エネルギー移動が 起こっていることがわかる. 配向度を励起側 $\left(f_{e x}\right)$, 蛍 光側 $\left(f_{e m}\right)$ に分けて評価した (Table 1). 配向度は以下 の式で定義する.

$$
\begin{aligned}
& f_{e x}=\left(I_{z z}+I_{z x}\right) /\left(I_{z z}+2 I_{z x}+2 I_{x z}+4 I_{x x}\right) \\
& f_{e m}=\left(I_{z z}+I_{x z}\right) /\left(I_{z z}+2 I_{z x}+2 I_{x z}+4 I_{x x}\right)
\end{aligned}
$$

励起波長にかかわらず, 励起の配向度 $f_{e x}$ より蛍光の 配向度 $f_{e m}$ の方が高い. また, 励起波長の影響について 比べると配向度は励起, 蛍光とも $310 \mathrm{~nm}$ 励起より, 350 $\mathrm{nm}$ 励起の方が配向度が高いことがわかる．励起は乱れ たセグメント,全トランスセグメントの両方で起きるが, 発光は全トランスセグメントからしか起きていないた め, 乱れたセグメントから全トランスセグメントへのエ ネルギー移動が起こる. 比較的配向が悪い高温相は摩擦 
方向に垂直な偏光もよく吸収し，配向のよい低温相部分 にエネルギー移動し，摩擦方向に強く偏光した発光を起 こす.

\section{4 おわりに}

サーモクロミック転移を起こすポリシラン，PDHS の 摩擦転写膜を作製し，その構造を詳細に検討した．配向 薄膜は配向したまま相転移するが，高温相から低温相へ の再結晶の際配向が乱れることがわかった．PDHS は摩 擦転写の過程において六方晶を経て配向薄膜となってい ると考えているが, 高温相から低温相への冷却の過程が 重要であると考えられる．相転移と配向構造の相関のよ り詳細な検討によって摩擦転写の機構にヒントが得られ るものと考えている.

分子配向薄膜は有機分子（高分子）を利用したナノテ クノロジーにとって重要なアイテムとなる．分子のもつ 性質を十分生かすため配向制御がますます重要になって くると思われる．筆者らはポリシランに限らず，機能性 高分子, 有機分子の配向制御, および構造評価の研究を よりいっそうすすめていきたい。

\section{文献}

1) F. C. Schilling, F. A. Bovey, D. D. Davis, A. J. Lovinger, R. B. McGregor, Jr., C. A. Walsh, and J. M. Zeigler, Macromolecules, 22, 4645 (1989).

2) K. Song, H. Kuzmany, G. M. Wallraff, R. D. Miller, and J. F. Rabolt, Macromolecules, 23, 3870 (1990).

3) N. Tanigaki, K. Yase, A. Kaito, and K. Ueno, Polymer, 36, 2477 (1995).

4) N. Tanigaki, K. Yase, and A. Kaito, Thin Solid Films, 273, 263 (1996).

5) N. Tanigaki, H. Kyotani, M. Wada, A. Kaito, Y. Yoshida, E. Han, K. Abe, and K. Yase, Thin Solid Films, 331, 229 (1998).

6) N. Tanigaki, A. Kaito, M. Yoshida, M. Wada, H. Kyotani, K. Yase, and Y. Tanabe, Mol. Cryst. Liq. Cryst. Sci. Technol., Sect. A, 337, 381 (1999).
7) N. Tanigaki, M. Yoshida, M. Wada, A. Kaito, and K. Yase, Mol. Cryst. Liq. Cryst. Sci. Technol., Sect. A, 349, 495 (2000).

8) 谷垣宣孝, 高分子論文集, 57, 515 (2000).

9) N. Tanigaki, Y. Iwase, A. Kaito, Y. Okada, N. Yamahira, and K. Yase, Mol. Cryst. Liq. Cryst. Sci. Technol., Sect. A, 370, 219 (2001).

10) J. C. Wittmann and P. Smith, Nature, 352, 414 (1991).

11) S. S. Patnaik and B. L. Farmer, Polymer, 33, 4443 (1992).

12) S. Furukawa, Thin Solid Films, 331, 222 (1998).

13) H. Kuzmany, J. F. Rabolt, B. L. Farmer, and R. D. Miller, J. Chem. Phys., 85, 7413 (1986).

14) F. C. Schilling, F. A. Bovey, A. J. Lovinger, and J. M. Zeigler, Macromolecules, 19, 2657 (1986)

15) H. Tachibana, M. Matsumoto, and Y. Tokura, Macromolecules, 26, 2520 (1993).

16) H. Frey, S. Sheiko, M. Möller, and J. C. Wittmann, Adv. Mater., 5, 917 (1993).

17) J. C. Baumert, G. C. Bjorklund, D. H. Jundt, M. C. Junrich, H. Looser, R. D. Miller, J. Rabolt, R. Sooriyakumaran, J. D. Swalen, and R. J. Twieg, Appl, Phys. Lett., 53, 1147 (1988).

18) S. Hoshino, H. Suzuki, M. Fujiki, M. Morita, and N. Matsumoto, Synth. Met., 89, 221 (1997).

19) W. C. Marra, P. Eisenberger, and A. Y. Cho., J. Appl. Phys., 50, 6927 (1979).

20) T. Horiuchi and K. Matsushige, Spectrochim. Acta, Part B, 48, 137 (1993).

21) N. Tanigaki, Y. Yoshida, A. Kaito, and K. Yase, J. Polym. Sci., Part B: Polym. Phys. Ed., 39, 432 (2001)

22) N. Tangiaki, H. Kyotani, K. Yase, and A. Kaito, Rep. Prog. Polym. Phys. Jpn., 38, 265 (1995).

23) H. Tachibana, Y. Kawabata, S. Koshihara, T. Arima, Y. Moritomo, and Y. Tokura, Phys. Rev. B: Condens Matter, 44, 5487 (1991).

24) J. F. Rabolt, D. Hofer, R. D. Miller, and G. N. Ficks, Macromolecules, 19, 611 (1986).

25) D. Fenwick, K. J. Ihn, F. Motamedi, J. C. Wittmann, and P. Smith, J. Appl. Polym. Sci., 50, 1151 (1993).

26) S. Nagamatsu, Y. Yoshida, N. Tanigaki, W. Takashima, K. Omote, K. Yase, and K. Kaneto, Macromolecules submitted

27) H. Kyotani, M. Shimomura, M. Miyazaki, and K. Ueno, Polymer, 36, 915 (1995).

28) M. M. Despotopoulou, R. D. Miller, J. F. Rabolt, and C. W. Frank, J. Polym. Sci., Part B: Polym. Phys. Ed., 34, 2335 (1996).

29) T. Seki and K. Ichimura, Langmuir, 13, 1361 (1997).

\section{Structure and Optical Properties of Poly(di- $\boldsymbol{n}$-hexylsilylene) Oriented Films}

Nobutaka TANIGAKI, ${ }^{* 1}$ Yuji Yoshida, ${ }^{* 1}$ Hiroko KyotanI, ${ }^{* 2}$ Akira KaIto, ${ }^{* 3}$ and Kiyoshi YASE ${ }^{* 1}$

${ }^{*}$ Photonics Research Institute, National Institute of Advanced Industrial Science and Technology (AIST) (Higashi, Tsukuba, 305-8565, Japan)

${ }^{* 2}$ National Institute of Materials and Chemical Research (Higashi, Tsukuba, 305-8565, Japan)

${ }^{* 3}$ Macromolecular Technology Research Center, National Institute of Advanced Industrial Science and Technology (AIST) (Higashi, Tsukuba, 305-8565, Japan)

Oriented thin films of poly(di- $n$-hexylsilylene) (PDHS) were prepared by the friction transfer method. We studied the preparation temperature condition. The orientational structure of the PDHS film was evaluated by the total reflection X-ray diffraction method. PDHS chains were aligned in the parallel to the friction direction and the PDHS crystallites had a preferred orientation aganist the substrate plane. Evaluation of the orientation during the phase transition revealed that the orientation was almost preserved, but was a little deteriorated during the cooling process. Moreover, polarized fluorescence sprectra were measured and the energy transfer was observed.

KEY WORDS Polysilane / Orientation / Total Reflection X-ray Diffraction / Polarized Spectra / Structure /

(Received June 3, 2002: Accepted July 24, 2002)

[Kobunshi Ronbunshu, 59(10), 623-630 (2002)] 